http://jmscr.igmpublication.org/home/ ISSN (e)-2347-176x ISSN (p) 2455-0450

crossref DOI: https://dx.doi.org/10.18535/jmscr/v8i11.51

Journal Of Medical Science And Clinical Research

\title{
Prognostic Value of Serum Acetylcholinesterase Levels in Acute Organophosphorus Poisoning: Study from an Intensive Care Unit at a Tertiary Care Teaching Hospital of North India
}

\author{
Authors \\ Ruksana Hamid", Rayees ul Hamid Wani ${ }^{2 *}$, Abdul Qayoom lone ${ }^{3}$, Suhail Sidiq ${ }^{4}$, \\ Mohammad Akbar Shah ${ }^{5}$, Abdul Waheed Mir ${ }^{6}$ \\ ${ }^{1}$ Department of Anaesthesiology and Critical Care, SKIMSMC Bemina, Srinagar \\ ${ }^{2}$ Department of Emergency Medicine, SKIMS Soura, Srinagar \\ ${ }^{3}$ Department of Anaesthesiology and Critical Care, SKIMS Soura, Srinagar \\ *Corresponding Author \\ Rayees ul Hamid Wani \\ Department of Emergency Medicine, SKIMS
}

\begin{abstract}
Introduction: Organophosphorus poisoningis of great concern in developing world as it affects the most productive age group of the society and has a high case fatality rate.

Objective: To assess the role of Serum acetylcholinesterase Levels in predicting morbidity and mortality in Acute Organophosphorus Poisoning.

Methodology: A prospective two year study was conducted to evaluate the possible impact of serum acetylcholinesterase levels on mortality and morbidity of patients admitted in ICU with diagnosis of Acute organophosphorus poisoning.

Results: A total of 102 cases were studied. The study revealed that the patients with serum acetylcholinesterase level $<2300 \mathrm{IU} / \mathrm{l}$ at presentation have greater morbidity and the patients with serum acetylcholinesterase level $<1800$ IU/l at presentation have greater mortality.

Conclusion: It can be suggested that the serum acetylcholinesterase levels can be used to predict mortality and morbidity in low resource settings of developing world.

Keywords: Organophosphorus, Prognosis, Poisoning, Acetylcholinesterase.
\end{abstract}

\section{Introduction}

Organophosphorus (OP) compounds are widely used as insecticides in the agricultural parts of the world. Its poisoning, both intentional and accidental, is a major global problem with a case fatality rate of $4-30 \%$. It is of great concern in developing world as it incidence is higher in young, economically active group of the society. ${ }^{1}$ Toxicity of organophosphorus compounds is the result of inhibition of acetylcholinesterase. The rapid accumulation of acetylcholine in the synaptic junctions of CNS and peripheral tissues results in range of muscarinic, nicotinic and central effects. ${ }^{2}$ Intermediate syndrome or type II paralysis usually occurs after 24-96 hours after acute cholinergic crisis. ${ }^{3}$ Death usually occurs due to cardiovascular and respiratory failure. ${ }^{4}$ The initial management of acute OP poisoning 
includes cardiorespiratory stabilization, decontamination, gastric lavage and activated charcoal. ${ }^{5}$ The mainstay of treatment is atropine and pralidoxime. ${ }^{6}$

A number of systems have been proposed for predicating outcome in organophosphorus poisoning, some rely on laboratory tests and others that use clinical parameters. The present study was conducted to assess the role of serum acetylcholinesterase in evaluate possible predictingmortality and morbidity of acute organophosphorus poisoning which will help in appropriate allocation of resources, including intensive care unit in a resource constrained setting.

\section{Aim and Objective}

To assess the role of Serum acetylcholinesterase Levels in predicting morbidity and mortality in Acute Organophosphorus Poisoning.

\section{Methodology}

A hospital based prospective study was conducted over a period of two years in Intensive care unit of a tertiary care teaching hospital. Following approval by institutional ethical committee and informed patient/attendant consent, all the patients of organophosphorus (OP) poisoning, diagnosed on the basis of clinical history and examination were included in the study. After initial assessment and resuscitation, all the patients were followed till the time of discharge/death and evaluated. Serum acetylcholinesterase levels were measured on admission.

The possible impact ofSerum acetylcholinesterase levelson mortality and morbidity factors(duration of hospital stay, need of admission to intensive care unit(ICU), and mechanical ventilation )were assessed.

Statistical Analysis: The data was analyzed using SPSS software version 20. The variables of interest were tabulated in terms of frequency and percentage. Pearson's chi square test was used to calculate $p$ value. A two- tailed $p$-value less than 0.05 was considered to be statistically significant.

\section{Results}

\section{Mortality and Serum Acetylcholinesterase levels}

A total of 15 cases expired out of 102 cases studied yielding a mortality rate of $14.7 \%$.

Table 1: Comparison of the Serum acetylcholinesterase levels between Patients who Survived and Expired

\begin{tabular}{|l|c|c|c|}
\hline & Survived & Expired & P value \\
\hline $\begin{array}{l}\text { Serum } \\
\text { Acetylcholinesterase } \\
\text { levels(IU/l) }\end{array}$ & 3367.4 & 1763.60 & $\leq \mathbf{0 . 0 0 0 1}$ \\
\hline
\end{tabular}

A statistically significant difference was noted between the patients who survived and those who expired.

\section{Morbidity parameters and Serum acetylcholinesterase levels}

Hospital Stay

Hospital stay was less than 7 days in 71 cases69.6\%) and more than 7 days in rest of the cases.

Table 2: Comparison of the Serum Acetylcholinesterase levels at presentation between Patients who had hospital stay $<7$ days and hospital stay $>7$ days

\begin{tabular}{|l|c|c|c|}
\hline & $\begin{array}{c}\text { Hospital } \\
\text { Stay }<7 \\
\text { days }\end{array}$ & $\begin{array}{c}\text { Hospital } \\
\text { Stay }>\mathbf{7} \\
\text { days }\end{array}$ & P value \\
\hline $\begin{array}{l}\text { Serum } \\
\begin{array}{l}\text { Acetylcholinesterase } \\
\text { levels(IU/l) }\end{array}\end{array}$ & 3510.4 & 2264.2 & $\leq \mathbf{0 . 0 0 0 1}$ \\
\hline
\end{tabular}

A statistically significant difference was noted between the patients who had hospital stay $<7$ days and hospital stay $>7$ days.

\section{Admission to intensive care unit (ICU)} A total of $64(62.7 \%)$ patients needed admission to intensive care unit, out of which 62 required mechanical ventilation.

Table 3: Comparison of the Serum Acetylcholinesterase levelsbetween Patients with or without admission to intensive care unit(ICU) .

\begin{tabular}{|l|c|c|c|}
\hline & $\begin{array}{c}\text { Not } \\
\text { admitted } \\
\text { to ICU }\end{array}$ & $\begin{array}{c}\text { Admitted } \\
\text { to ICU }\end{array}$ & P value \\
\hline $\begin{array}{l}\text { Serum } \\
\begin{array}{l}\text { Acetylcholinesterase } \\
\text { levels(IU/L) }\end{array}\end{array}$ & 4792.45 & 2125.63 & $\leq \mathbf{0 . 0 0 0 1}$ \\
\hline
\end{tabular}


A statistically significant difference was noted between the patients who were admitted to ICU and who did not required admission to ICU.

\section{Need of mechanical ventilation}

A total of $64(62.7 \%)$ patients needed admission to intensive care unit ,out of which 62 required mechanical ventilation.

Table 4: Comparison of the Serum Acetylcholinesterase levelsat presentation between Patients with or without requirement of mechanical ventilation.

\begin{tabular}{|l|c|c|c|}
\hline & $\begin{array}{c}\text { Not } \\
\text { ventilated }\end{array}$ & $\begin{array}{c}\text { Required } \\
\text { ventilation }\end{array}$ & P value \\
\hline $\begin{array}{l}\text { Serum } \\
\text { Acetylcholinesterase } \\
\text { levels(IU/L) }\end{array}$ & 4762.45 & 2125.63 & $\leq \mathbf{0 . 0 0 0 1}$ \\
\hline
\end{tabular}

A statistically significant difference was noted between the patients who were required mechanical ventilation and who did not required mechanical ventilation.

\section{Duration of mechanical ventilation}

Out of total 62 cases, 8 cases were ventilated for more than 3 days.

Table 5: Comparison of the Serum Acetylcholinesterase levelsbetween Patients with duration of mechanical ventilation $<3$ days and > 3 days

\begin{tabular}{|l|c|c|c|}
\hline & $\begin{array}{c}\text { Duration }<\mathbf{3} \\
\text { days }\end{array}$ & $\begin{array}{c}\text { Duration }>\mathbf{3} \\
\text { days }\end{array}$ & P value \\
\hline $\begin{array}{l}\text { Serum } \\
\begin{array}{l}\text { Acetylcholinesterase } \\
\text { levels(IU/L) }\end{array}\end{array}$ & 3512.44 & 2268.26 & $\leq \mathbf{0 . 0 0 0 1}$ \\
\hline
\end{tabular}

A statistically significant difference was noted between the patients with duration of mechanical ventilation $<3$ days and $>3$ days.

\section{Discussion}

Organophosphorus poisoning is one of the most common poisoning in developing world due to their easy availability and ignorance about their proper handling and toxicity. Despite high mortality and complications associated with it, no definite prognostic criteria have been set, which might help to assess patients at presentation.

Studies have advocated use of various scales and parameters to assess the severity of poisoning and prognosis. Peradenya organophosphorus poisoning (POP) scale, modified Driesbach criteria, Glasgow coma scale, APACHE II, SAPS, SOFA, serum cholinesterase levels, serum amylase, serum lipase, creatinine kinase and prolonged QT interval are a few among them. ${ }^{7}$

Our study assessed the role of serum acetylcholinesterase levels at presentation on mortality and morbidity.

Serum acetylcholinesterase levels at presentation were significantly higher in the patients who survived than patients who expired. Similiar results were obtained by Rehiman et al. ${ }^{8}$

Patients with shorter hospital stay, who were not admitted in ICU and did not require mechanical ventilation had higher levels of Serum acetylcholinesterase on presentation. This finding was consistent with studies conducted by Kang et al, ${ }^{9}$ Many et $\mathrm{al}^{10}$ and Banday et al. ${ }^{11}$ Need of ventilation is also more in patients with low serum acetylcholinesterase levels. ${ }^{1}$

The serum acetylcholinesterase can be used for confirmation of diagnosis and for predicting patients who are at increased risk of mortality and morbidity. It is suggested that the patients with levels of serum acetylcholinesterase less than $2300 \mathrm{IU} / \mathrm{L}$ should be immediately referred to an Intensive care Unit with possibility of need for mechanical ventilation. In resource constrained settings, it will help in decision making regarding referral to a higher center or for keeping patients under observation, after initiation of treatment and can lead to significant reduction of mortality and morbidity resulting from acute organophosphorus poisoning.

\section{Conclusion}

It is concluded that Serum acetylcholinesterase levels <2300IU/1 on presentation have greater morbidity and mortality in our setup. It is suggested that the patients with these levels of serum acetylcholinesterse should be immediately referred to an Intensive care Unit with possibility of need for mechanical ventilation. In resource constrained settings, it will help in decision making regarding referral to a higher center or for 
keeping patients under observation, after initiation of treatment.

\section{Source of Funding: Nil}

Conflict of Interest: Nil

Ethical Clearance: Taken

\section{Bibliography}

1. Suhail Sidiq et al.A Study of Possible Prognostic Predictors of Organophosphorus Poisoning International Journal of Medical Science and Current Research (IJMSCR) Volume 2, Issue 2; March-April 2019; Page No. 32-39.

2. Jeyaratnam J. Acute pesticide poisoning: A major global health problem. World Health Stat Q 1990; 43:139-44.

3. Yang CC, Deng JF. Intermediate syndrome following organophosphate insecticide poisoning. J Chin Med Assoc 2007;70:467-72.

4. Yanagisawa N, Morita $\mathrm{H}$, Nakajima $\mathrm{T}$. Sarin experiences in Japan: Acute toxicity and long-term effects. J Neurol Sci 2006; 249:76-85.

5. Wadia RS. Treatment of organophosphate poisoning. Indian J Crit Care Med 2003; $17: 85-7$.

6. Singh S, Chaudhry D, Behera D, Gupta D, Jindal SK. Aggressive atropinization and continuous pralidoxime infusion in patients with severe organophosphate poisoning : Experience of northwest Indian hospital. Him Exp Toxicol 2004; 23: 5659.

7. Raddi D, Anikethana G. Liver Enzymes for Assessment of Severity of Organophosphorus Poisoning. Int J Med Health Sci. Jan 2015, Vol-4;1: 60-63.

8. Rehiman S, Lohani SP, Bhattaria MD. Correlation of serum cholinesterase level, clinical score at presentation and severity of organophosphorus poisoning. J Nepal Med Assos, 2008;47(170): 47-52.
9. Kang EJ, Seok SJ, Lee KH, Gil HW, Yang JO, Lee EY et al. Factors for determining survival in acute organophosphate poisoning. The Korean journal of internal medicine, 2009; 24(4).

10. Many MS, prashant V, Akila P,Sums MN, Bass an a good apps H. A retrospective analysis of serial measurement of serum cholinesterase in acute poisoning with organophosphate compounds. Toxicol Into, 2012;19: 255-9.

11. Banday TH, Tathineni B, Desai MS, Naik V. Predictors of morbidity and mortality in organophosphorus poisoning: A case study in a rural hospital in Karnataka, India. North American journal of medical sciences June 2015; 7(6): 259-265. 